Samuka Vol 5 No 2 : hlm 169-177

SAMUKA

Jurnal Samudra Ekonomika

https://ejurmalunsam.id/index.php/jse

\title{
PENGARUH PERTUMBUHAN EKONOMI DAN USAHA MIKRO KECIL MENENGAH TERHADAP PENDAPATAN ASLI DAERAH DI KOTA LANGSA
}

\author{
Nadya Fitri Setiawan ${ }^{3}$, Nurlaila Hanum ${ }^{2}$, Asnidar $^{3}$ \\ setiawan15022000@gmail.com \\ nurlailahanum@unsam.ac.id \\ asnidar@unsam.ac.id
}

$1^{*, 2,3}$ Program Studi Ekonomi Pembangunan, Universitas Samudra, Langsa

J1. Prof. Dr. Syarief Thayeb, Meurandeh, Kota Langsa, Aceh 24416

Received: September 2021; Accepted: September 2021 Published: September 2

\begin{abstract}
Abstrak
Penelitian ini bertujuan untuk mengetahui pengaruh pertumbuhan ekonomi secara parsial terhadap pendapatan asli daerah Kota Langsa, untuk mengetahui pengaruh usaha mikro kecil menengah secara parsial terhadap Pendapatan Asli Daerah di Kota Langsa, untuk mengetahui pengaruh pertumbuhan ekonomi dan usaha mikro kecil menengah secara simultan terhadap Pendapatan Asli Daerah di Kota Langsa. Penelitian ini menggunakan pendekatan kuantitatif. Model penelitian ini menggunakan metode analisis regresi linear berganda dengan menggunakan aplikasi Eviews versi 11. Hasil persamaan regresi linear berganda $Y=7,43 E+10+12.654,08 X 1+-334.669 X 2+$ e. Dimana nilai Koefisien regresi pertumbuhan ekonomi sebesar 12654,08, menunjukan bahwa apabila terjadi peningkatan pertumbuhan ekonomi 1 persen maka akan menyebabkan Pendapatan Asli Daerah di Kota Langsa meningkat sebesar 12654,08 persen. Nilai Koefisien regresi Usaha Mikro Kecil Menengah sebesar minus 334669, menunjukan bahwa apabila terjadi peningkatan jumlah Usaha Mikro Kecil Menengah sebesar 1 persen, maka akan menyebabkan Pendapatan Asli Daerah di Kota Langsa meningkat sebesar minus 334669 persen. Hasil penelitian ini dengan tingkat signifikansi 96,71\% menunjukan bahwa pertumbuhan ekonomi berpengaruh positif dan signifikan terhadap Pendapatan Asli Daerah dan Usaha Mikro Kecil menengah berpengaruh tetapi tidak signifikan terhadap Pendapatan Asli Daerah di Kota Langsa
\end{abstract}

Kata kunci: Pendapatan Asli Daerah (PAD), Pertumbuhan Ekonomi, Usaha Mikro Kecil Menengah (UMKM).

\begin{abstract}
This study aims to determine the effect of partial economic growth on local revenue of Langsa City, to determine the effect of micro, small and medium enterprises partially on Regional Original Income in Langsa City, to determine the effect of economic growth and micro small and medium enterprises simultaneously on Regional Original Income. in Langsa City. This study uses a quantitative approach. This research model uses multiple linear regression analysis method using the E-views version 11. The results of the multiple linear regression equation $\mathrm{Y}=7.43 \mathrm{E}+10+$ 12654.08X1 + -334669X $2+$ e. Where the value of the regression coefficient of economic growth is 12654.08, indicating that if there is an increase in economic growth of 1 percent, it will cause Regional Original Income in Langsa City to increase by 12654.08 percent. The regression coefficient value for Micro, Small and Medium Enterprises is minus 334669, indicating that if there is an increase in the number of Micro, Small and Medium Enterprises by 1 percent, it will cause Regional Original Income in Langsa City to increase by minus 334669 percent. The results of this study with a significance level of $96.71 \%$ showed that economic growth had a positive and significant effect on Regional Original Income and Micro, Small and Medium Enterprises had an effect but not significantly on Regional Original Income in Langsa City.
\end{abstract}

Keywords: Regional Original Income (PAD), Economic Growth, Micro, Small and Medium Enterprises (UMKM).

\section{PENDAHULUAN}


Daerah Kabupaten dan Daerah Kota menjadi titikberat pelaksanaan otonomi daerah hal ini dimulai dengan adanya penyerahan sejumlah kewenangan yang berasal dari pemerintah pusat ke pemerintah daerah yang bersangkutan. Dalam kegiatan desentralisasi harus disertai dengan penyerahan kewenangan dan pengalihan pembiayaan. Otonomi daerah adalah suatu kebebasan yang dimiliki daerah dalam membuat peraturan daerah, menyusun, dan melaksanakan kebijakan. Serta mengelola keuangan daerah secara mandiri (Sujarweni, 2015).

Rosemary et al. (2016) mengungkapkan adanya alasan yang diterapkan oleh kebijakan otonomi pada daerah karena pemerintah pusat tidak mampu sendiri mengawasi pembangunan daerah secara keseluruhan oleh sebab itu pemerintah pusat melimpahkan kewenangan terhadap pemerintah daerah untuk mengatur dan mengurus kepentingan-kepentingan daerahnya sendiri. Pendapatan Asli Daerah adalah sumber pembiayaan yang sangat penting di mana komponen utamanya adalah penerimaan yang berasal pajak daerah dan retribusi daerah. Pendapatan Asli Daerah (PAD) sebagai salah satu penerimaan daerah menentukan tingkat kemandirian suatu daerah. Daerah yang dikatakan dapat menghasilkan PAD yang besar maka daerah tersebut juga mampu melaksanakan desentralisasi fiskal dengan baik dan ketergantungan terhadap pemerintah pusat berkurang.

Dalam melaksanakan kewenangan Pemerintah Daerah, Pemerintah Pusat akan mentransfer Dana Perimbangan yang terdiri dari Dana Alokasi Khusus (DAK), Dana Alokasi Umum (DAU), dan bagian daerah dari Dana Bagi Hasil yang terdiri dari pajak dan sumber daya alam hal ini tertera dalam UU No.32/2004. Pemerintah daerah juga memiliki dana dari daerahnya sendiri selain dari dana perimbangan yaitu dana dari Pendapatan Asli Daerah, pembiayaan, dan lain- lain pendapatan. Menurut UU No. 33/2004 mengenai dana perimbangan Keuangan antara Pemerintah Pusat dan Pemerintah Daerah, disebutkan bahwa Pendapatan Asli Daerah adalah pendapatan yang diperoleh daerah yang dipungut berdasarkan peraturan daerah yang sesuai dengan peraturan perundangundangan. Pemerintah daerah memiliki kewenangan untuk mendanai pelaksanaan otonomi daerah sesuai dengan potensi daerah yang dananya berasal dari Pendapatan Asli Daerah sebagai perwujudan desentralisasi hal ini tertera dalam pasal 3. Kebijakan dalam penggunaan dana-dana tersebut diserahkan kepada Pemerintah daerah. Dana yang diberikan oleh Pemerintah Pusat diharapkan dapat digunakan secara efektif dan efisien oleh Pemerintah Daerah untuk meningkatkan pelayanannya kepada masyarakat. Kebijakan dalam penggunaan dana tersebut sudah seharusnya dapat dilakukan secara transparan dan akuntabel.

Keberhasilan suatu daerah dalam usaha membangun ekonomi daerah dipengaruhi oleh beberapa faktor ekonomi, yaitu: sumber daya manusia (labor supply, education, discipline, motivation), pembentukan modal (capital formation), sumber daya (natural resources), teknologi dan kewirausahaan (technology and entrepreneurship) (Suryana,2000)

Tabel 1. Perkembangan Pendapatan Asli Daerah di Kota Langsa Tahun 2014-2019 (rupiah)

\begin{tabular}{ccc}
\hline Tahun & PAD ( Rupiah) & Perkembangan (\%) \\
\hline 2014 & 114.168 .702 .058 & - \\
2015 & 108.942 .418 .961 & $-4,56$ \\
2016 & 121.369 .467 .376 & 1,14 \\
2017 & 120.138 .956 .033 & $-0,1$ \\
2018 & 121.321 .358 .035 & 0,9 \\
2019 & 120.504 .670 .904 & $-0,6$ \\
\hline
\end{tabular}

Sumber: Badan Pusat Statistik Kota Langsa 2021

Berdasarkan tabel 1 dapat dilihat Pendapatan Asli Daerah di Kota Langsa sebesar Rp. 114.168.702.058, kemudian perkembangan pada tahun 2015 adalah -4,56. Pada tahun 2016 perkembangan Pendapatan Asli Daerah sebesar 1,14\% dan 2017 mengalami penurunan sebesar 0,1\% karena dalam beberapa pendapatan mengalami penurunan seperti dari hasil retribusi daerah dan lain-lain PAD yang sah (BPS Kota Langsa, 2020). Kemudian pada tahun 2018 mengalami 
kenaikan 0,9\%, dan 2019 menurun menjadi sebesar -0,6\% karena beberapa jenis pendapatan mengalami penurunan pendapatan dari hasil retribusi daerah dan lain-lain PAD yang sah (BPS Kota Langsa, 2020).

Sumber dana pembangunan daerah sebagian besar di dapatkan dari pemerintah pusat, sementara itu kewenangan pemerintah daerah dalam mengatur penggunaan dana tersebut relatife terbatas. Semakin besar pajak daerah yang diterima maka semakin meningkat pula Pendapatan Asli Daerah nya. Dan begitu pula semakin besar pajak yang diperoleh maka dapat lebih muda membiayai pengeluaran dalam melaksanakan wewenang dan tanggung jawabnya kepada masyarakat seperti membantu dan memfasilitasi sarana dan prasarana masyarakatdalam sektor pendidikan, pertanian, kesehatan,dan lain-lain. Ada beberapa variable yang mempengaruhi Pendapatan Asli Daerah yaitu pertumbuhan ekonomi dan usaha mikro kecil menengah.

Dalam menentukan suatu perekonomian negara yang baik maka dapat dilihat dari pertumbuhan ekonomi daerah tersebut. Terutama dalam melakukan analisis mengenai pembangunan ekonomi yang telah dilaksanakan suatu negara ataupun suatu daerah. Suatu perekonomian dapat mengalami perubahan apabila produksi barang dan jasa meningkat dari tahun sebelumnya. Kegiatan perekonomian dapat menghasilkan penambahan pendapatan dan kesejahteraan masyarakat pada waktu tertentu apabila suatu negara atau suatu wilayah terus menunjukan peningkatan pertumbuhan ekonomi dan menggambarkan bahwa perekonomian negara atau wilayah tersebut berkembang dengan baik (Amir, 2007).

Pendapatan nasional yang tinggi dan pertumbuhan ekonomi yang cepat akan membuat proses pembangunan yang lebih mudah. Banyak negara yang syarat utama dalam menciptakan penurunan kemiskinan yaitu pertumbuhan ekonomi. Peningkatan dalam pertumbuhan ekonomi memang tidak cukup dalam mengatasi penurunan kemiskinan, namun menjadi sesuatu yang diperlukan. Menurut Wongdesmiwati (2009), apabila pemerataan pendapatan tidak dilakukan dengan baik maka pertumbuhan ekonomi yang tinggi tidak dapat menurunkan tingkat masyarakat miskin. Pertumbuhan ekonomi menjadi kunci sebuah wilayah. Salah satunya Kota Langsa yang memiliki luas 262,41 km2 mempunyai penduduk sejumlah 186.827 jiwa dengan komposisi 94.037 penduduk laki-laki dan 92.754 jiwa perempuan. Dengan kondisi tersebut maka kepadatan penduduk sebesar 779 jiwa/ km2. Sedangkan pertumbuhan penduduk sebesar 2,14\% per tahun (Badan Pusat Statistik Kota Langsa 2020) Pertumbuhan Ekonomi sering diukur dengan menggunakan Produk Domestik Regional Daerah (PDRB).

Tabel 2. Perkembangan Produk Domestik Regional Bruto Atas Dasar Harga Konstan di Kota Langsa Tahun 2014-2019

\begin{tabular}{ccc}
\hline Tahun & PDRB (Juta Rupiah) & Perkembangan (\%) \\
\hline 2014 & $3.113 .491,08$ & - \\
2015 & $3.244 .671,74$ & 4,21 \\
2016 & $3.390 .389,66$ & 4,49 \\
2017 & $3.540 .718,30$ & 4,43 \\
2018 & $3.701 .200,91$ & 4,53 \\
2019 & $3.865 .510,33$ & 4,44 \\
\hline
\end{tabular}

Sumber: Badan Pusat Statistik Kota Langsa 2021

Dilihat dari tabel 2 perkembangan pada tahun 2015 sebesar 4,21\%. Pada tahun 2016 PDRB Kota Langsa meningkat sebesar 4,49\%. Pada tahun 2017 mengalami peningkatan kembalisebesar 4,43\%, Kemudian pada tahun 2018 mengalami perkembangan sebesar 4,53\% dan pada tahun 2019 mengalami perkembangan sebesar 4,44\% (BPS Kota Langsa, 2020). Kurangnya entrepreneurship baik dalam individu, organisasi dan masyarakat adalah salah satu penyebab kegagalan dalam pencapaian pertumbuhan ekonomi dan pembangunan ekonomi suatu negara. Kewirausahaan 
sangat berperan dalam pembangunan ekonomi. Dalam meningkatkan pembangunan ekonomi, maka kewirausahaan harus memahami betul dalam mendirikan suatu usaha baik usaha mikro, kecil maupun usaha menengah dan adanya jiwa kewirausahaan dalam diri setiap individu. Dalam hal ini pemerintah pusat maupun pemerintah daerah tidak mampu menyediakan lapangan kerja sepenuhnya untuk merekrut para pencari kerja. Berdasarkan data DISPERINDAGKOP dan UKM Kota Langsa (2020), jumlah UMKM adalah 34.029 di Kota Langsa. Adapun hal ini dapat dilihat pada tabel dibawah ini.

Tabel 3. Jumlah Usaha Mikro Kecil Menengah Kota Langsa Tahun 2014-2019

\begin{tabular}{ccc}
\hline Tahun & Jumlah UMKM (unit) & Perkembangan (\%) \\
\hline 2014 & 649 & - \\
2015 & 2.631 & 3,5 \\
2016 & 3.376 & 2,83 \\
2017 & 875 & $-7,42$ \\
2018 & 271 & $-6,9$ \\
2019 & 2.496 & 8,21 \\
\hline
\end{tabular}

Sumber: Diskoperindagkop Dan Ukm Kota Langsa, 2021

Dari tabel 3 dapat dilihat ada 649 UMKM yang tercatat di DISPERINDAGKOP dan UKM Kota Langsa pada tahun 2014. Perkembangan UMKM pada tahun 2015 mengalami kenaikan sebesar 3,5\%. Pada tahun 2016 berkembang sebesar 2,83\%. Pada tahun 2017 menurun menjadi $0,56 \%$ karena adanya penurunan di semua usaha baik itu Mikro Kecil maupun Menengah, dan 2018 mengalami penurunan kembali sebesar $-0,69 \%$ karena semua bidang usaha mengalami penurunan, dan mengalami kenaikan menjadi 8,21\% pada tahun 2019.

Kebijaksanaan yang dilakukan pemerintah dalam pengembangan usaha mikro kecil menengah (UMKM) dalam jangka panjang dapat meningkatkan potensi UMKM karena dapat melakukan proses pembangunan nasional, khususnya dalam pemerataan pembangunan yang dapat membuka peluang lapangan kerja dan peningkatan pendapatan (Priyo, 2006). Banyaknya goncangan krisis ekonomi namun UMKM adalah kelompok usaha yang jumlahnya paling besar yang mampu bertahan hingga saat ini. Ada beberapa kriteria yang dipergunakan untuk mendefinisikan pengertian dan kriteria Usaha Mikro Kecil dan Menengah hal ini tertaut dalam Undang-Undang Nomor 20 Tahun 2008.

Paramasivan dan Selvam (2013) melakukan penelitian yang dan hasilnya menunjukkan pentingnya Usaha Mikro Kecil Menengah (UMKM) dalam meningkatkan pendapatan negara, yaitu hasil penelitianya bahwa Usaha Mikro, Kecil dan menengah merupakan memenuhi kebutuhan lokal serta ada tuntutan besar yang memiliki keunikan karakter dari produk dan jasa. Adapun tujuan penelitian ini adalah: (1) untuk mengetahui pengaruh pertumbuhan ekonomi secara parsial terhadap pendapatan asli daerah Kota Langsa, (2) untuk mengetahui pengaruh usaha mikro kecil menengah secara parsial terhadap Pendapatan Asli Daerah di Kota Langsa, (3) untuk mengetahui pengaruh pertumbuhan ekonomi dan usaha mikro kecil menengah secara simultan terhadap Pendapatan Asli Daerah di Kota Langsa.

\section{LANDASAN TEORI}

\section{Pendapatan Asli Daerah}

Pendapatan Asli Daerah yaitu semua pendapatan yang bersumber dari potensi daerah seperti pajak daerah, laba BUMD, retribusi daerah, dana perimbangan dan pendapatan pemerintah daerah lainnya yang sah menurut undang-undang. Besarnya Pendapat Asli Daerah suatu daerah dapat memperlihatkan bahwa kemampuan keuangan daerah lebih kuat dibandingkan dengan yang memiliki Pendapatan Asli Daerah lebih rendah dan hal ini akan mengurangi tingkat ketergantungan dengan pemerintah di atasnya (Sutrisno, 2005) . Berikut sumber-sumber Pendapatan Asli Daerah (PAD) dalam Undang-undang No 33 tahun 2004 yaitu: 


\section{Pendapatan Asli Daerah (PAD) terdiri dari:}

a. Hasil pajak daerah adalah suatu pungutan daerah yang peraturannya telah ditetapkan oleh daerah untuk pembiayaan rumah tangganya sebagai badan hukum publik.

b. Hasil retribusi daerah adalah suatu pungutan yang secara sah menjadi pungutan daerah sebagai pembayaran pemakaian atau karena mendapatkan pemakaian jasa atau karena memperoleh jasa pekerjaan, usaha atau milik pemerintah daerah bersangkutan.

c. Hasil pengelolaan kekayaan daerah dan hasil perusahaan milik daerah yang dipisahkan adalah pendapatan daerah yang didapat dari keuntungan bersih yang diperoleh dari perusahaan daerah yang berupa dana pembangunan daerah dan untuk untuk anggaran belanja daerah yang disetor ke kas daerah, baik perusahaan daerah yang dipisahkan, sesuai dengan motif pendirian dan pengelolaan, maka sifat perusahaan dareah adalah suatu kesatuan produksi yang bersifat menambah pendapatan daerah, member jasa, menyelenggarakan kemamfaatan umum, memperkembangkan perekonomian daerah..

d. Lain-lain pendapatan daerah yang sah adalah suatu pendapatan yang tidak termasuk dalam jenis-jenis retribusi daerah, pajak daerah, dan pendapatan dinas-dinas. Lain-lain usaha daerah yang sah digunakan pemerintah daerah dalam melakukan kegiatan yang menghasilkan baik berupa suatu materi dalam kegitan tersebut yang bertujuan untuk menunjang, melapangkan, dan memantapkan suatu kebijakan daerah disuatu bidang tertentu.

2. Retribusi daerah adalah pembayaran atas jasa atau pemberian izin tertentu yang disediakan atau diberikan oleh Pemerintah Daerah untuk kepentingan orang pribadi atau badan.

3. Dana perimbangan diperoleh melalui bagian pendapatan daerah dari penerimaan pajak bumi dan bangunan baik dari perkotaan, pedesaan, bea perolehan hak atas tanah dan bangunan, dan pertambangan sumber daya alam. Dana perimbangan terdiri dari dana alokasi khusus, dana alokasi umum, dan dana bagi hasil.

4. Lain-lainpendapatan daerah yang sah adalah pendapatan daerah dari sumber lain misalnya sumbangan pihak ketiga kepada daerah yang dilaksanakan sesuai dengan peraturan perundang-undangan yang berlaku.

\section{Pertumbuhan Ekonomi}

Pertumbuhan ekonomi sebagai kenaikan jangka panjang dalam kemampuan suatu negara untuk menyediakan banyak jenis barang-barang ekonomikepada penduduknya hal ini sesuai dengan definisi dari Kuznet (Jhingan, 2012). Adam Smith dalam bukunya dengan judul An Igniry Into The Nature And Cause Of The Wealt Nations, menganalisis sebab berlakunya pertumbuhan ekonomi dalam faktor yang menentukan pertumbuhan ekonomi. Selain Adam Smith, beberapa ahli ekonomi klasik lainnya seperti Ricardo, Malthus, Struart Mill, juga membahas masalah perkembangan ekonomi. Pertumbuhan ekonomi adalah perkembangan fiskal produksi barang dan jasa yang berlaku di suatu negaraseperti pertambahan dan jumlah produksi barang industri, perkembangan infrastruktur, pertambahan produksi sektor jasa dan pertambahan produksi barang modal. Capaian tingkat pertumbuhan pendapatan nasional riil adalah suatu gambaran kasar untuk mengetahui pertumbuhan ekonomi suatu negara (Sukirno, 2011). Dapat disimpulkan bahwa pertumbuhan ekonomi adalah suatu kenaikan pendapatan nasional riil atau produk domestig bruto dalam jangka panjang dan dapat menyebabkan barang ataupun jasa yang di produksi meningkat dan kemakmuran masyarakat ikut meningkat.

\section{Usaha Mikro Kecil dan Menengah}

Undang-Undang nomor 20 tahun 2008 membahas mengenai definisi tentang Usaha Mikro, Kecil, dan Menengah (UMKM). Berikut ini adalah jabaran definisi dari UMKM:

1. Usaha Mikro yaitu usaha produktif milik orang perorangan atau badan usaha perorangan 
yang memenuhu kriteria usaha mikro sebagaimana diatur dalam Undang-Undang.

2. Usaha Kecil yaitu usaha ekonomi produktif yang berdiri sendiri yang dilakukan oleh orang perorangan atau badan usaha yang bukan merupakan anak perusahaan atau bukan cabang yang dimiliki, dikuasai, atau menjadi bagian langsung maupun tidak langsung dari Usaha Menengah atau Usaha Besar yang memenuhi kriteria Usaha Kecil sebagaimana dimaksud dalam Undang-Undang.

3. Usaha Menengah yaitu usaha ekonomi produktif yang berdiri sendiri, dilakukan oleh orang perorangan atau badan usaha yang bukan merupakan anak perusahaan ataupun cabang perusahaan yang dimiliki atau menjadi bagian baik langsung maupun tidak langsung dan Usaha Kecil atau Usaha Besar dengan jumlah kekayaan dan hasil penjualan tahunan sebagaimana diatur dalam Undang-Undang.

\section{METODE PENELITIAN}

Penelitian ini membahas mengenai Pengaruh Pertumbuhan Ekonomi Dan Usaha Mikro Kecil Menengah (UMKM) Terhadap Pendapatan Asli Daerah (PAD) Di Kota Langsa. Jangka waktu penelitian ini yaitu selama 6 bulan dimulai dari Desember 2020 sampai dengan Juni 2021. Jenis data yang digunakan adalah data kualitatif dan data kuantitatif dengan memperhatikan jenis data dan sumber-sumber data. Metode pengumpulan data ini menggunakan teknik Penelitian kepustakaan yaitu cara untuk memperoleh data yang penulis lakukan dengan membaca buku-buku, jurnal, dan artikel yang berhubungan dengan judul tulisan. Penelitian lapangan ini dilakukan dengan cara menelaah dokumen yang telah disediakan oleh Badan Pusat Statistik, Dinas KOPERINDAG KOP Kota Langsa tahun 2020. Metode analisis data digunakan untuk mengetahui pengaruh pertumbuhan dan Usaha Mikro Kecil Menegah (UMKM) terhadap Pendapatan Asli Daerah di Kota Langsa,maka peneliti menggunakan aplikasi Eviews (2021). Metode analisis data ini menggunakan model persamaan untuk menghitung regresi linier berganda. Untuk kepentingan penelitian ini, maka persamaan di atas dimodifikasikan ke persamaan berikut:

Dimana :

$$
\mathrm{Y}=\mathrm{a}+\mathrm{b}_{1} \mathrm{X}_{1}+\mathrm{b}_{2} \mathrm{X}_{2}+\mathrm{e}
$$

$\mathrm{Y}=$ Pendapatan Asli Daerah

a $=$ konstanta

$\mathrm{b}=$ koefisien regresi

$\mathrm{X}_{1}=$ pertumbuhan ekonomi

$\mathrm{X}_{2}=$ usaha mikro kecil menengah

$\mathrm{e} \quad$ error

\section{HASIL PENELITIAN DAN PEMBAHASAN \\ Hasil Penelitian}

Untuk menganalisis pengaruh Pertumbuhan Ekonomi Dan Usaha Mikro Kecil Menengah Terhadap Pendapatan Asli Daerah di Kota Langsa dapat diketahui dari data sekunder yang dianalisis dengan menggunakan data regresi linear berganda, uji koefisien determinasi. Adapun hasil regresi Linear Berganda Berganda dan Uji autokorelasi variabel Pertumbuhan Ekonomi dan Usaha Mikro Kecil Menengah pada Pendapatan Asli Daerah yang menggunakan pengolah data pada program Eviews 11 dengan hasil sebagai berikut ini:

Tabel 4. Hasil Regresi Linear Berganda

Dependent Variable: PAD

\begin{tabular}{ccccr}
\hline \hline Variable & Coefficient & Std. Error & t-Statistic & Prob. \\
\hline \hline C & $7.43 \mathrm{E}+10$ & $2.59 \mathrm{E}+10$ & 2.874374 & 0.0638
\end{tabular}




\begin{tabular}{lrlrr}
\multicolumn{1}{c}{ PE } & 12654.08 & \multicolumn{1}{c}{7356.214} & 1.720189 & 0.1839 \\
\multicolumn{1}{c}{ UMKM } & -334669.0 & \multicolumn{1}{c}{1628900.} & -0.205457 & 0.8504 \\
\hline \hline R-squared & 0.501650 & Mean dependent var & $1.18 \mathrm{E}+11$ \\
Adjusted R-squared & 0.169416 & S.D. dependent var & $5.10 \mathrm{E}+09$ \\
S.E. of regression & $4.64 \mathrm{E}+09$ & Akaike info criterion & 47.66268 \\
Sum squared resid & $6.47 \mathrm{E}+19$ & Schwarz criterion & 47.55856 \\
Log likelihood & -139.9880 & Hannan-Quinn criter. & 47.24588 \\
F-statistic & 1.509930 & Durbin-Watson stat & 2.752992 \\
Prob(F-statistic) & 0.351805 & & \\
\hline \hline
\end{tabular}

Sumber: Output Eviews 11, 2021

Berdasarkan tabel 4 maka persamaan regresi linear berganda dalam penelitian ini adalah sebagai berikut :

$$
\mathrm{Y}=7,43+12.654,08 \mathrm{X}_{1}-334.669 \mathrm{X}_{2}+\mathrm{e} \text {. }
$$

Persamaan ini dapat di intrepetasikan sebagai berikut :

a. Konstanta sebesar 7,43 berarti bahwa Pendapatan Asli Daerah yaitu sebesar 7,43 persen, apabila pertumbuhan ekonomi dan Usaha Mikro Kecil Menengah (tidak mengalami perubahan).

b. Nilai unstandardized coefficients $\beta_{1}$ pertumbuhan ekonomi sebesar 12.654,08. Menunjukan bahwa apabila terjadi peningkatan pertumbuhan ekonomi 1 persen maka akan menyebabkan Pendapatan Asli Daerah di Kota Langsa meningkat sebesar 12.654,08 persen dengan asumsi cateries paribus.

c. Nilai unstandardized coefficients $\beta_{2}$ sebesar -334.669. Menunjukan bahwa apabila terjadi peningkatan jumlah Usaha Mikro Kecil Menengah sebesar 1 persen, maka akan menyebabkan Pendapatan Asli Daerah di Kota Langsa meningkat sebesar -334.669 persen dengan asumsi cateries paribus.

Dari hasil uji t dapat dijelaskan, hasil estimasi koefisien variabel pertumbuhan ekonomi sebesar 12.654,08 dan tidak signifikan pada prob. $0,1839>\alpha=0,05$. Artinya secara parsial pertumbuhan ekonomi berpengaruh positif dan tidak signifikan terhadap Pendapatan Asli Daerah di Kota Langsa. Sedangkan untuk hasil estimasi koefisien variabel Usaha Mikro Kecil Menengah sebesar -334.669 dan tidak signifikan pada prob. 0,8504 $>\alpha=0,05$. Artinya secara parsial Usaha Mikro Kecil Menengah berpengaruh negatif dan tidak signifikan terhadap Pendapatan Asli Daerah di Kota Langsa.

Hasil uji $\mathrm{F}$ dalam penelitian ini diperoleh sebesar $0,351805>\alpha=0,05$ maka dapat dinyatakan secara simultan pertumbuhan ekonomi dan Usaha Mikro Kecil Menengah berpengaruh tidak signifikan terhadap Pendapatan Asli Daerah di Kota Langsa.

Dalam penelitin ini diperoleh nilai $R$ Square sebesar 0,5016 atau 50,16\%, artinya variabel pertumbuhan ekonomi dan Usaha Mikro Kecil Menengah mempengaruhi Pendapatan Asli Daerah di Kota Langsa sebesar 50,16\%, sedangkan sisanya 49,84\% dipengaruhi oleh faktor-faktor lain diluar penelitian ini.

Uji Autokorelasi besar nilai Durbin-Watson (DW) menunjukan sebesar 2,7529. Berdasarkan tabel Durbin-Watson (DW) yang menggunakan signifikansi sebesar 5\% dengan jumlah (N) sebanyak 12 dan jumlah variabel independen (k) sebesar 2, maka didapatkan nilai batas atas atau Durin Upper (DU) sebesar 1,5794 dan batas bawah atau Durbin Lower (DL) sebesar 0,8122. Maka hasil perhitungan DW, Posisi DW berada di antara 4-DU dengan 4-DL. Sehingga, pada tabel model ini adalah ragu-ragu.

\section{Pembahasan}

Pengaruh Pertumbuhan Ekonomi Terhadap Pendapatan Asli Daerah 
Besaran koefisien variabel pertumbuhan ekonomi sebesar 12.654,08 dan tingkat signifikan pada prob. $0,1839>\alpha=0,05$. Artinya pertumbuhan ekonomi berpengaruh positif dan tidak signifikan terhadap Pendapatan Asli Daerah di Kota Langsa. Maka pernyataan hipotesis pertama yang menyatan bahwa pertumbuhan ekonomi berpengaruh signifikan terhadap Pendapatan Asli Daerah Kota Langsa, ditolak. Hal ini tidak sesuai dengan hasil penelitian yang dilakukan oleh Gunantara dan Dwirandra (2014), Iswara dan Indrajaya (2014) yang menyimpulkan bahwa pertumbuhan ekonomi secara parsial berpengaruh terhadap Pendapatan Asli Daerah. Adanya perbedaan dalam hasil penelitian ini tentunya tidak terlepas dari keadaan dan kondisi geologi, sosial, dan perekonomian suatu daerah.

Pengaruh Usaha Mikro Kecil Menengah (UMKM) Terhadap Pendapatan Asli Daerah

Besaran koefisien variabel Usaha Mikro Kecil Menengah sebesar -334.669 dan tingkat signifikan pada prob. 0,8504 $>\alpha=0,05$. Artinya Usaha Mikro Kecil Menengah berpengaruh negatif dan tidak signifikan terhadap Pendapatan Asli Daerah di Kota Langsa. Maka pernyataan hipotesis kedua yang menyatakan bahwa Usaha Mikro Kecil Menengah berpengaruh signifikan terhadap Pendapatan Asli Daerah di Kota Langsa, ditolak. Hal ini tidak sesuai dengan penelitian sebelumnya yang dilakukan oleh Paramasivan dan Selvam (2013) yang menyatakan bahwa Usaha Mikro Kecil Menengah merupakan tulang punggung serta memberikan kontribusi dalam pengembangan pendapatan daerah.

Pengaruh Pertumbuhan Ekonomi Usaha Mikro Kecil Menengah Terhadap Pendapatan Asli Daerah Secara simultan diperoleh nilai prob. sebesar 0,351805 $>\alpha=0,05$ maka dapat dinyatakan secara simultan pertumbuhan ekonomi dan Usaha Mikro Kecil Menengah berpengaruh tidak signifikan terhadap Pendapatan Asli Daerah di Kota Langsa. Maka pernyataan hipotesis ketiga yang menyatakan bahwa secara simultan pertumbuhan ekonomi dan Usaha Mikro Kecil Menengah berpengaruh signifikan terhadap Pendapatan Asli Daerah di Kota Langsa, ditolak. Berdasarkan hasil analisis pengujian dengan menggunakan Eviews pertumbuhan ekonomi dan Usaha Mikro Kecil Menengah berpengaruh secara signifikan terhadap Pendapatan Asli Daerah. Hasil penelitian ini tidak sesuai dengan Paramasivan dan Selvam (2013) yang mendapati hasil bahwa Usaha Mikro Kecil Menengah dapat meningkatkan pendapatan suatu negara. Hal ini juga didukung dengan hasil penelitian yang dilakukan oleh Gunantara dan Dwirandra (2014) menyatakan bahwa pertumbuhan ekonomi yang baik dapat meningkatkan Pendapatan Asli Daerah.

\section{SARAN}

Berdasarkan hasil penelitian ini dan kesimpulan penulis mencoba untuk memberikan saran sebagai berikut.

1. Pemerintah Kota Langsa diharapkan mampu menjaga kestabilan laju pertumbuhan ekonomi dan mampu meningkatkan sembilan sektor yang ada dalam PDRB.

2. Perlu adanya sosialisasi kesadaran wajib pajak terhadap pengusaha mikro karena pajak tersebut juga akan kembali kepada masyarakat dengan adanya fasilitas penunjang dalam kegiatan usaha yang dilakukan oleh masyarakat.

3. Bagi penelitian selanjutnya mampu menambahkan sumber Pendapatan Asli Daerah dan Usaha Mikro Kecil Menengah sehingga mampu menunjang penelitian yang lebih baik lagi sehingga mampu lebih berkontribusi terhadap Pendapatan Asli Daerah di Kota Langsa.

\section{REFERENSI}

Amir, Amri. (2007). Pengaruh Inflasi dan Pertumbuhan Ekonomi Terhadap Pengangguran di Indonesia (online). http://amriamir.wordpress.com. 
BPS (2021) Badan Pusat Statistik Kota Langsa

Dinas Koperasi Industri Koperasi dan UKM Kota Langsa 2021.

Jhingan, M. L. (2012). Ekonomi Pembangunan dan Perencanaan. Jakarta: Rajawali Press.

Paramasivan, C. P dan Mari S. (2013). Progress and Performance of Micro, Small and Medium Entreprises in India. International Journal of Manajement Studies, 2(4).

Rosemary, O., Justine, C., dan Barry, B. (2016). Local Government Financial Autonomy: A Comparative Analysis of Nigeria and Brazil. Arabian Journal of Bussiness and Management Review (OMAN Chapter), 5(10), 38-54.

Sukirno, Sadono. (2011). Makro Ekonomi Teori Pengantar Edisi Ketiga. Rajawali Pers, Jakarta

Arsyad, Lincolin. (2010). Ekonomi Pembangunan. Yogyakarta: UPP STIM YKPN.

Suryana, (2000). Ekonomi Pembangunan: Problematika dan Pendekatan, Jakarta: Salemba Empat.

Undang-undang (UU) No. 33 Tahun 2004 Perimbangan Keuangan antara Pemerintah Pusat dan Pemerintahan Daerah.

Undang-Undang Nomor 20 Tahun 2008 Tentang Usaha Mikro, Kecil, dan Menengah.

Undang-Undang Republik Indonesia Nomor 32 Tahun 2004 Tentang Pemerintahan Daerah. 